Nowoczesne Systemy Zarządzania

Zeszyt 12 (2017), nr 3 (lipiec-wrzesień)

ISSN 1896-9380, s. 41-58

Modern Management Systems

Volume 12 (2017), No. 3 (July-September)

ISSN 1896-9380, pp. 41-58
Instytut Organizacji i Zarządzania

Wydział Cybernetyki

Wojskowa Akademia Techniczna

w Warszawie

Institute of Organization and Management

Faculty of Cybernetics

Military University of Technology

\title{
Convergence of IT and business \\ in connected economy as a driver for organizations' digital transformation
}

\author{
Konwergencja IT i biznesu \\ w połączonej gospodarce jako siła napędowa \\ dla cyfrowej rewolucji w organizacjach
}

\author{
Rosanna Sibora \\ University of Gdańsk, Faculty of Management
}

\begin{abstract}
This article discusses the importance of digital transformation and cross-departmental collaboration between IT and business units in the age of connected economy. The aim of the article is to highlight the most crucial aspects of IT-business relationship, contributing to the successful realization of organization's transformation process. The author also provides a roadmap for how companies might undergo a digital transformation. Well designed and executed digital transformation roadmap will contribute to the establishment of solid IT-business relationship and IT's strategic role within the company, as well as - above all - to the digital-driven value creation process and in this way to company's competitive advantage.

Keywords: digital transformation, IT-business relationship, competitive advantage, value creation, change management, strategic management, shadow IT
\end{abstract}

Abstrakt: Artykuł omawia znaczenie cyfrowej transformacji oraz współpracy pomiędzy działem IT a biznesem w dobie połączonej gospodarki cyfrowej. Celem artykułu jest ukazanie najważniejszych aspektów mających wpływ na relacje pomiędzy IT a biznesem, przyczyniających się do zwieńczonej sukcesem realizacji procesu transformacji przedsiębiorstwa. Autorka przedstawia model planu pozwalającego przedsiębiorstwu dokonać cyfrowej transformacji. Prawidłowo zaprojektowany i wdrożony w życie plan transformacji cyfrowej pozwoli na stworzenie stabilnej relacji między IT a biznesem, w konsekwencji ugruntuje strategiczną rolę IT w organizacji oraz umożliwi przedsiębiorstwu zdobywanie przewagi konkurencyjnej bazującej na zasobach cyfrowych.

Słowa kluczowe: cyfrowa transformacja, zarządzanie relacją na linii IT i biznes, przewaga konkurencyjna, budowanie wartości, zarządzanie zmianą, zarządzanie strategiczne, IT cieni 


\section{Introduction}

In the age of connected economy, where value creation process is based on "technology-enabled links between people, machines, and organizations" (Harvard Business Review, 2016, p. 1), companies are facing new challenges. New technological solutions emerge both with advantages and disadvantages for companies. Organizations rethink and redefine their value-creation processes in order to create an innovation-driven competitive advantage, but many are still struggling to get it right. Correct implementation of new solutions into the existing structure can be challenging for non-digital native organizations. However, if the company will not disrupt itself, it will be disrupted by anyone else. It is just a question of time, as described already in the '40s by Joseph Schumpeter, who named the phenomenon "creative destruction" (Schumpeter, 2003, pp. 81-86). In the age of the fourth industrial revolution - which "is characterized by a fusion of technologies that is blurring the lines between the physical, digital, and biological spheres" (World Economic Forum, 2016) - new technologies are emerging at a pace comparable to the speed of light. The use of advanced technology-driven solutions accelerates the development rate in all areas, leading to a reduction of destructive cycle length. Enterprises face the challenge of continuous innovation and reconfiguration in order to stay competitive, which can be described as "digital Darwinism" (Segal, 2016). Companies that neglect or underestimate the need for iterative transformation will not survive in the long run, as their inflexible and frozen business models will inevitably become outdated and will be replaced by a competitor sooner than they think. Merely $12 \%$ of companies listed in Fortune 500 list from 1955 are still present in the 2015 list (Perry, 2015). What distinguishes the connected economy leader from laggards is mainly the understating of real threat which brings digital disruption along with the comprehension of meaning of IT leadership in the transition process (Harvard Business Review, 2016, p. 2). 60\% of companies listed in the Fortune 100 ranking have already established teams responsible for digital transformation and the number is expected to grow by 20\% in 2017 (Harvard Business Review, 2016, p. 8).

As the examples of Uber or Airbnb prove, a company does not necessarily need to own goods to make profit out of these. In the age of sharing economy - "The peer-to-peer-based activity of obtaining, giving, or sharing the access to goods and services, coordinated through community-based online services" (Hamari et al., 2015 , p. 1) - competitive advantage can be achieved without physical resources as taxis in case of Uber, or rooms in case of Airbnb. Although Airbnb does not own a single room, it is the biggest rental service worldwide and a serious competitor for big hotel chains. We are observing a shift of dominance from product and service economy to connected economy.

A wise integration of modern technologies into value creation processes is a condition sine qua non for successful digital transformation in the connected 
economy era. In the dynamic and hypercompetitive environment, it is not enough to gain a technology-based competitive advantage only. It is a true challenge to keep the leader position over time. Rather than trying to sustain the competitive advantage, companies should become their own competitors by disrupting itself (McQuivey, 2013, p. 101). Only by iteratively creating a new competitive advantage can a company keep its leading position in a rapidly changing environment. Digital transformation leaders are already investing 34\% of IT budget on digital transformation and the investments are planned to rise up to $44 \%$ by 2018 (Boulton, 2016).

Who is responsible for running a company's digital transformation? Is it business or is it IT? How should they work together to achieve the best outcome? The purpose of this article is to explain the role of IT department in the digital transformation and provide a model for how companies might undergo this transition process to fully leverage their potentials in the era of digital disruptions. The main research question is: how does IT-business relationship influence the digital transformation process of a company and what are the enablers bursting IT-business convergence. This article focuses on non-digital native companies, whose core field of action is not related to tech industry.

The article is structured as follows. The first section presents IT-business relationship problems. The subsequent section explains the reasons of insufficient IT-business relationship, followed by a detailed description of IT-business convergence enablers. The article concludes with a design of a roadmap for how companies might undergo a digital transformation, as well as presents the stages of digital transformation based on Kurt Lewin's model.

\section{IT-business relationship problems}

Organization structure, characterized by a strict split between IT and business divisions, is a potential source of many issues and this might hamper successful innovations and transformation processes. The perception of IT by business colleagues may differ from organization to organization. CIOs are facing a challenging task of IT alignment and improvement of IT-business relationship. Being a CIO means that you are your unit's CMO, responsible for IT's image and its role within the company. Many organizations need to change the perception of IT first in order to proceed with the enterprise's digital transformation led or co-led by IT. Only $13 \%$ of business stakeholders see IT organization as a business leader. Just $30 \%$ of business units consider IT as a business partner. For $38 \%$ of employees IT is just a service provider and $18 \%$ see IT as a cost center (CIO.com, 2015). This proves that role of the IT in many large organizations is marginalized, leading in extreme cases to a ghost-IT syndrome. Some employees do not acknowledge the existence of their IT colleagues, while chasing after their own targets. As long as the in-house 
IT services and applications are running smoothly, no one realizes the efforts hidden behind the user interfaces. Paradoxically, downtimes contribute to the raising awareness of IT's existence. Lack of communication from IT leads to a bad image within a company. In an enterprise supported by a ghost-IT, synergies between IT and business are not exploited as necessary to facilitate digital transformation. Since business units do not have sufficient IT-knowledge to recognize digital possibilities and to make the most out of available technologies, the rate of digital transformation in companies with ghost-IT will be lower compared to the companies supported by an IT, which is considered a recognized business leader and allowed to contribute to the business strategy. The worst the IT's perception within an organization, the less influence a CIO has over digital transformation.

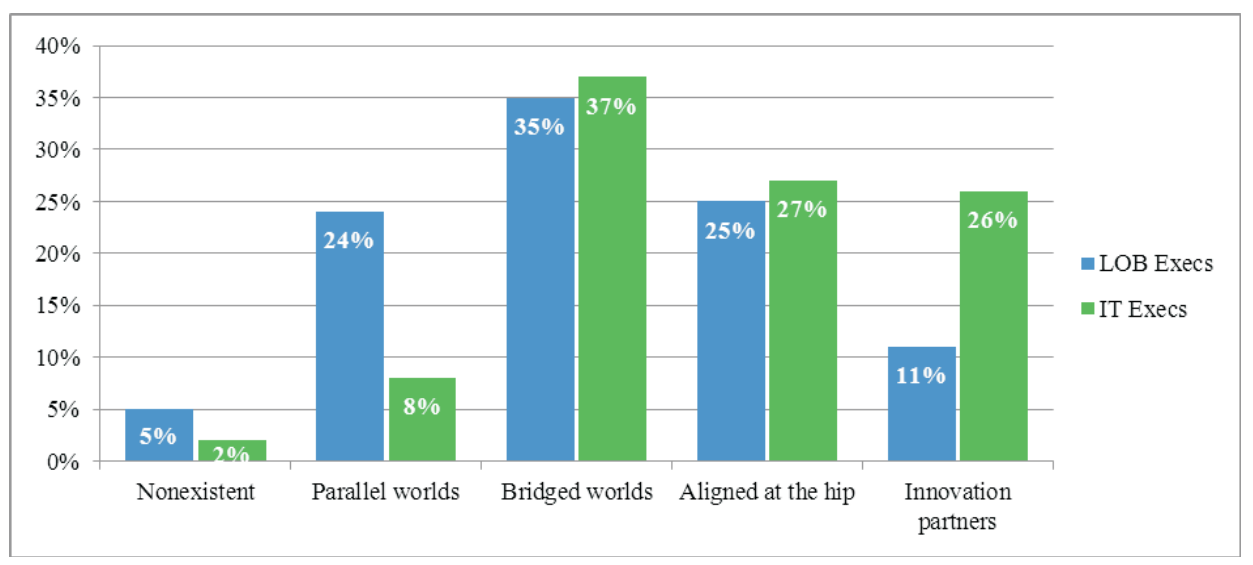

Fig. 1. How do you view the relationship between IT and the lines of business?

Source: own elaboration based on CIO.com, 2016b

All the same, IT is seen as an obstacle in many organizations. From business units' perspective, involvement of IT in a decision process or implementation of new systems only decelerates a project. $60 \%$ of functional CIOs are being blamed if their business colleagues do not achieve the set goals (CIO.com, 2016a, p. 2). In fact, wrong choice of technologies can cause inflexibility. Being "one velocity IT" may actually slow down the projects of business divisions.

Only 57\% of companies' investments in technology are controlled by IT divisions (CIO.com, 2016a, p. 6). The remaining 43\% can be described as a shadow IT. Shadow IT refers to IT investments, which are made without involving organization's IT department. 33\% of marketing divisions have technology spending power (CIO.com, 2016a, p. 6). In organizations where IT is seen as a service provider or cost center, only in $49-51 \%$ of the cases CIO and CMO are selecting the technologies together (Stackpole, 2016, p. 13). If a CEO agrees that marketing divisions are allowed to make technology choices alone, why does she or he not ask the IT 
organization to run the next marketing campaign? The stronger an IT's strategic role within company, the lower the percentage of a shadow IT. If the company's IT is seen as a service provider or just a mere cost center it is more likely that the shadow IT percentage is higher than those companies where IT is recognized as a business partner or game changer. Since nearly every innovation is a digital solution, it is essential to provide necessary IT support and services: "If they [IT organization] do not or are slow to do so, the business stakeholders will do it anyway. Indeed, the spiraling growth of «shadow IT» being experienced by most enterprises is testament to that. IT organizations must adapt to that reality" (Gartner, 2016b).

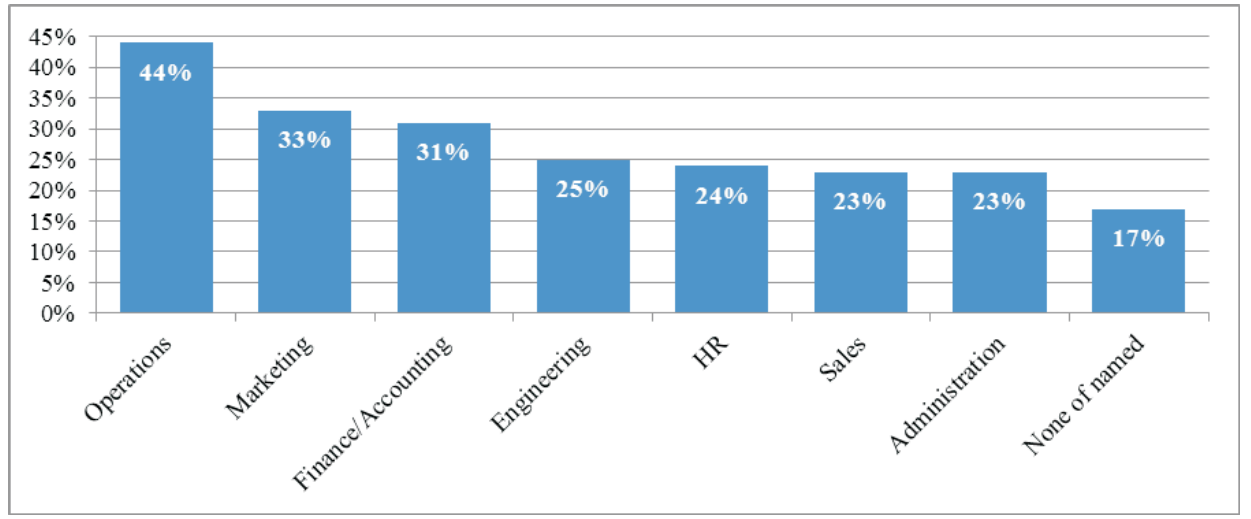

Fig. 2. Business units, who have technology spending power

Source: own elaboration based on IDG Enterprise, 2016

Shadow IT leads to a lack of holistic perspective on all technologies and (not-yet) digitally-driven solutions in the whole company. Implementing single systems isolated from an organization's digital ecosystem results in an island-like application portfolio, which will eventually cause trouble for IT. This results not only in system and know-how silos, but also in organizational and strategy silos. In a research conducted by Harvard Business Review and IBM, silos and insufficient collaboration have been identified as the most serious obstacles on the way to becoming a connected economy leader (Harvard Business Review, 2016, pp. 10-11). In companies with high level of shadow IT, nearly every business unit has its own Robinson Crusoe, building up an isolated digital environment: "Building a wide variety of incompatible processes and systems may seem like progress, but it limits bigger opportunities" (Westerman et al., 2014, p. 16). Gartner predicts that in $2018,90 \%$ of companies "will lack a postmodern application integration strategy" (Gartner, 2016a), which is necessary to manage a complex application portfolio. ROI from shadow IT investments, which are not co-piloted by IT organization, is lower compared to ROI from a technology investment conducted by IT caused mainly by lack of IT know-how of business employees. Lifecycle cost of shadow IT investments 
is usually higher than lifecycle cost of comparable IT project. Implementation of off-the-shelf software can also have negative impacts on a company's competitive advantage, as well as on the innovation capability of employees.

\section{Reasons of insufficient IT-business relationship}

The reasons for IT's rather non-prestigious image may lie, among other things, in the IT itself. Small and inflexible IT teams may not move at the pace required to embrace changing realities of the market and business needs. Low IT-business relationship focus, which results in lack of a due understanding of business goals, may hamper the goal-oriented collaboration on projects. An IT employee without a deep understanding of business is just another nerd. IT's language may be difficult to understand for a business employee with a low digital maturity. Also, a clash of different working cultures of the divisions may cause problems while working together on projects. Lack of IT strategy or an IT strategy isolated from business strategy leads to the formation and preservation of parallel IT-business universes.

Business employees with low digital maturity may lack an interest in implementing digital solutions. They may even fear from cooperation with IT and usage of new technologies. Some may be afraid of being replaced by digital solutions.

Bureaucratic organization hampers innovative potential of company's employees and makes organizational change and bottom-up initiatives difficult: "The bureaucratic method of transacting business and the moral atmosphere it spreads doubtless often exert a depressing influence on the most active minds" (Schumpeter, p. 207).

Top management may also be jointly responsible for the bad image of IT within company, cultivating the perception of IT as a cost center, resulting in a low number of IT headcounts, small or even no increase of IT headcounts over the years, low budget, as well as not assigning IT challenging priority tasks or even not letting IT lead innovative digital projects. With little or no faith from top management, IT will only remain a cost center. Lack of top management's support causes difficulties while leading a change process. Without management support each transformation project is doomed to fail before it even started. As proven by empirical analyses, top-down leadership is essential: "(...) we saw no examples of successful transformation happening bottom-up" (Westerman et al., 2014, p. 14).

\section{Enablers for IT-business convergence}

Technology per se does not create business value, unless you are a tech company. Open-source or commercial technologies are widely available, self-developed applications can be replicated and data is not always exclusive. Neither technology, 
nor data can assure sustainable competitive advantage. Data per se is not a strategic resource: "Data without use is overhead" (Cox, 2011, pp. 19-20). However, access to technologies and data is a requirement for digitally-driven value creation. In the age of connected economy it is a data-based interaction between human beings, machines and organization, which mostly contributes to value creation. The right combination of these components is a fundamental key to competitive advantage. Innovation and competitive advantage do not come from data or technologies, but from the right people being able to use the right technologies in order to generate value. Technologies and data sources should not be chosen in isolation from business cases: "(...) while most organizations have moved to embrace their data, they have also fallen prey at times to collecting data for data's sake, without first taking in the business value of data" (Sweetwood, 2016, p. 29).

In order to draw most value from technology-based solutions a company requires a strategic IT-business relationship management directed towards innovationdriven value creation. IT-business relationship can be defined as an iterative process of continuous development. Only the synergies of multidisciplinary teams (Rudder, 2016b) - with background both in tech and business - can lead to a successful digital transformation: "We need to connect everyone in order to innovate. We want to be very diverse. There is an unwritten rule that the more diverse we are, the more chances we have to innovate" (Deloitte, 2013, p. 7). Two plus two might be much more than four, if the energies of all divisions are combined properly. Instead of letting teams work separately, the power and capabilities of available human resources should be combined in order to maximize the outcome. However, it must be noted that establishing IT-business relationship may be challenging for many companies. This chapter discusses the possibilities of accomplishing this challenge.

The first and most important step in order to forge IT-business relationship is to establish a strategic role of CIO: "To be successful, a CIO must set and execute a strategy to use information and digital assets to continuously improve the customer experience, operational processes, and business models" (Segal, 2016). In extreme cases IT's transition from an isolated cost center to innovative and well connected business leader can be a very long process. However, the role of CIO is crucial for unlocking the potential of digital transformation: "(...) if digital C-Suite leaders are not first and foremost inspiring people to be creative problem solvers, their organizations simply will not be able to move with the speed or the resiliency necessary to survive in the fast-paced digital world" (Rudder, 2016b). Already 84\% of CIOs report growing importance of their role for business divisions (CIO.com, 2016a, p. 2). According to the "State of the CIO" survey, CIOs who actively contribute to the development of business strategy and who make company growth easier, may recon better access to company's resources in future projects (CIO.com, 2016a, p. 2 ). This proves that most CEOs understand the importance of IT organization and IT is also able to prove the ability to influence value creation process. IT strategy 
needs to support the business goals (Peppard, Ward, 2016, pp. 35, 125-126, 327), so companies must keep aligning IT strategy with business strategy continuously. To accelerate the digital transformation, CIOs must be permanently en route with an innovation evangelist hat on: "CIOs must look beyond technological improvements and focus on business innovations to develop a comprehensive business assurance strategy" (Segal, 2016).

Why is it so important to have IT in the leading position while embracing digital transformation? IT's digital DNA makes data-centric and innovative thinking possible. These capabilities are needed for a deep dive into algorithmic business and in-house education in the field of data-driven value creation. IT team understands the power of data and is able to unlock its hidden potential. This makes IT responsible for establishing a new mindset in the whole organization. The mindset and paradigm shift creates an environment, where each employee understands the relevance of data and company's data strategy (Sweetwood, 2016, pp. 29, 34). Without a doubt, only IT team possesses profound digital expertise, necessary to make reasonable technology choices, which suit best to existing application portfolio, making its implementation, future maintenance and communication between applications much easier. IT is able to recognize the real potential of new technologies, spotting seasonal hypes. IT can suggest a combination of technologies needed to deal with a problem which others in a company cannot even imagine getting solved. Every digital solution generates data and data needs to be managed correctly. Letting IT lead company's technology choices and design IT infrastructure adapted to business' volume, velocity and variety will result in reliable, efficient and connected systems, which is one of the pillars of connected economy. Connected economy leaders, being able to use data as source of information at high pace, have observed its stronger impact on company's revenue than competitors with lower connectivity level (Harvard Business Review, 2016, p. 1): "Digital Masters are 26 percent more profitable than their industry competitors" (Westermal et al., 2014, p.20). As the example of marketing organization's transformation at SAS proves, reaching business goals nowadays stands and fails with a strong, business-oriented IT support: "While marketing requires new technical skills, we are not the experts when it comes to the technology. Now that we are relying so heavily on data and analytical tool to do our work, we need more help from experts in how we can both create and collect enterprise-level customer data, while also ensuring its integrity. Without good, clean data, we cannot market very well, no matter how sophisticated our tools are" (Sweetwood, 2016, p. 78). Departments which in the past contributed to high level of shadow IT will notice in the long run that they are not able to look after the purchased solutions, as it was the case at SAS: "We recognized that not only was this going to duplicate resources within our organization, but we simply did not have the in-house expertise to maintain the system. We had to have the IT team as our partner instead. We recognized that we need IT for its expertise in 
storing, integrating, modeling, and providing consistent structure for our data" (Sweetwood, 2016, p. 79).

Nevertheless, chosen technologies must always meet the needs of businesses, so continuous dialogue between businesses and IT units is crucial for sustainable success. Raising the awareness regarding the complexity of digital solutions and the education of those in business units about technology implementation process simultaneously means involving the future product-owners into the decision process, making them co-investors (Rudder, 2016a). In this way, companies' shadow ITs will shrink.

$64 \%$ of CIOs agree that effective communication with business stakeholders is the most important factor influencing IT-business relationship (CIO.com, 2016a, p. 7). It is crucial for IT teams to understand the business units they are working for, as well as their goals (Topinka, 2014, p. 3). The communication is a major pillar of successful collaboration, so connect with business units and cultivate ongoing exchange. Only a deep understanding of business goals will facilitate a solid IT role in a project team. Martha Heller, author of Be the Business: CIOs in the New Era of IT observes the positive development in the field of IT-business relationship: "the biggest change since I wrote «The CIO Paradox» is how the walls between IT and the rest of the company are coming down. (...) The role of the CIO today (...) is not to manage the IT function in isolation (...)" (Rudder, 2016a). What distinguishes connected economy leaders is creation of IT-business relationship characterized by collaborative engagement rather than competition: "The key to effective change management is communication. We talk about it constantly - from the top down, the bottom up, and all around" (Harvard Business Review, 2016, pp. 2, 7).

Once the connection between IT and business units has been established it is extremely important to keep it alive, by scheduling follow-up sessions and creating a plan for a community work. CIOs must encourage IT team members to educate themselves and pass the know-how to their business colleagues: "(...) a core sense of curiosity and a desire to both learn and teach (...). (...) these innate qualities in an employee make them virtually unstoppable in IT" (Franklin, 2006). It is important to keep in contact with every single department to forge permanent cross-departmental collaboration. It is also influential to brainstorm with the team on how to maintain the relationship and continuous digital education in a way that suits the company's culture best. These might be through "ask me anything sessions" (Sweetwood, 2016, p. 124), "Digitize the Business Council" (Sweetwood, 2016, p. 77), new business unit (Westerman et al., 2014, p. 10), regular meetups, hackathons and internal pitches or a yearly IT convention. Best practices, success stories and story-telling can be used to spread the information on digital transformation. Companies must also create an awareness that business problems are regarded as IT problems and vice versa. They should begin talking about "our" problems in order to break down the silo mentality. 
In some cases it might be necessary to change the organization structure in order to support the convergence between IT and business. To perpetuate the contact and strategic relationship, hiring an integration analyst or a relationship manager jointly can be considered as it has been done at SAS: "The integration analyst is present at the outset of any marketing initiative to ensure marketing needs are met using the latest technologies that fit into the IT infrastructure. (...) IT gains much deeper understanding of the business and acts as a communication bridge between the two departments, which ultimately helps IT deliver a better product for marketing" (Sweetwood, 2016, p. 80).

Many organizations see IT as an obstacle for their projects. To address this, companies can introduce a bimodal IT model, focusing on speed and flexibility rather than accuracy. Focus should be on continuous delivery, based on agile methods, and integration of business colleagues in the application development process: "If you are in IT, ship software; if you are not getting software into your customers' hands, you are failing" (Rudder, 2016a). Companies should decide carefully on where to apply the traditional mode and where the fast mode would do a relatively better job, bearing in mind that the fast mode - also called "exploratory" (Gartner, 2016b) suits better in the early stages of innovation (Gartner, 2015), when it is necessary to try many things out. Technologies and infrastructure that do not slow down the work must be adopted. New team members or external freelancers must be hired to increase a team's flexibility in order to support business, when necessary. To justify new headcounts use data, to visualize the workload of your team (Sweetwood, 2016, p. 141). Think carefully about whether it is the best choice to outsource some tasks. Cooperation with external consultants leads to external know-how silos. Retaining institutional knowledge can be the main reason to increase the number of internal resources, instead of outsourcing.

While conducting a transition process, it is essential to establish a failure culture across all divisions, as it was the case at SAS: "We have built a culture that encourages and rewards us for taking risks and trying something different. (...) Here you can be creative and comfortable about experimenting" (Sweetwood, 2016, p. 139). Every change is risky, but only by taking some risks are companies able to innovate. It is essential to conquer the fear of failure and explore unknown paths by trying things out. Each employee should be allowed to test her/his ideas. As a role model in this area serves Adobe, where - thanks to Adobe Kickbox (Adobe, 2016) - everyone can refine their ideas.

The role of external environment should by no means be underestimated. Each organization is a part of a dynamic ecosystem. The most important "components" - company's end customers, paying your salaries - are outside of the company, so those running the business should keep looking out of the window. Some companies resemble castles surrounded by a moat. If they are not continuously monitoring trends emerging out there, that company will surely fail. To forge the connection with 
external environment and to gain better understanding of the ecosystem, initiatives on two parallel levels, personal and data-driven, must be undertaken. Therefore, it is highly significant to be up to date with technological changes and disruptions by attending conferences or meetups and exchanging best practices and success stories with other companies. It is especially vital to consider cooperation with startups to gain new perspectives. Companies should keep checking what customers' needs and expectations are by observing the changes in external environment and talking to customers, as it was the case at Starbucks: "Through its My Starbucks Ideas site, Starbucks has collected more than 150000 customer-submitted ideas to improve its products, customer experience, and corporate initiatives" (Westerman et al., 2014, pp. 38-39). Ultimately, what remains to be done is to enrich the insights captured at the interpersonal level through information gained from big data analysis to have a bigger picture: "Data should be the lifeblood for designing compelling customer experience. By adding science to the art, data helps companies move from guesswork to inspired predictions and continuous hypotheses testing" (Westerman et al., 2014, p. 39).

How to convert a non-existent business-IT relationship into a permanent cooperation? IT should be proactive and send its team members into the field. Companies should support employees who are willing to contribute to organizational change. People, who are able to question the status-quo will be the most important pillar of the change. This is possible thanks to those managers who believe in the innovative power of criticism (Verganti, 2016, p. 5) and encourage the constructive nonconformity (Gino, 2016) among their employees.

The benefits of IT-business cooperation include better understanding of business goals and processes on IT's side, increased understanding of IT solutions and processes on business' side, updated overview over existing IT portfolio, cultivation of IT-business exchange, higher acceptance of chosen technology and choice of a solution, which suits best both parties, meeting technological criteria, as well as solving a business case. This is a clear win-win situation for both IT and business. ROI of technology investments, analyzed by both business units and IT, is higher compared to the shadow IT investments.

All the mentioned enablers of IT-business convergence above constitute a basis for successful innovation and digital transformation. Those aspects should be worked on and developed continuously - which will eventually enable the realization of transformation roadmap.

\section{Designing digital transformation roadmap}

What do companies need to transform from a non-digital native company into a digitally-driven enterprise? They are supposed to start with designing a transformation roadmap for the company's journey of change. First step is (1) doing 
a status-quo review by asking such questions as: Where are we? Who are our internal users and end customers? Where are they? What are the needs of our colleagues and end customers? ${ }^{1}$ What are the use cases to solve? While searching for the answers the user- and data-centric thinking should be applied. The digital solutions are not an art in itself, these should satisfy peoples' needs, whether they are internal or external customers. Design Thinking, as a user-centric approach, might be helpful for transformation team while trying to understand the internal and external customers' needs and to identify not-yet-solved use cases as part of status-quo review ${ }^{2}$. Moreover, IT must explore the business environment in full depth by conducting one-to-one interviews with colleagues, not only to find out what their problems, challenges or dreams are, but to forge an IT-business bond. IT team members must consider accompanying their colleagues for 2-3 days to experience their daily routine and better understand the reality of business. Many employees will be feeling taken care of and heard. By giving them a voice, managers will gain important stakeholders who will contribute to the projects among other things by being project promoters beyond the boundaries of the business. The status-quo on IT's side should be reviewed as well by raising an inventory of IT's portfolio - applications and available data - in a form accessible for non-tech employees. Defined status-quo will make it possible to measure the success to come in future.

Once the status-quo has been defined, transformation team should proceed with (2) a synthesis of interviews. First, companies must focus on value creation and problem solving, and keep in mind that digital solutions can support value creation process by improving their product or service, creating new product or service, monetizing existing assets in a better way, improving interactions with customers, reducing costs, increasing productivity, reducing time-to-market, providing insights supporting the decision-making process, and enabling more efficient allocation of resources. Upon having a bigger picture of colleagues' needs, their digital maturity, their potential, as well as upon understanding business goals, transition team will be able to perform a SWOT-analysis (Rudder, 2016b). Based on the collected use cases, they should prepare a use case matrix and classify identified use cases by urgency, influence on business value and complexity. In this way transformation team will be able to prioritize the use cases, making it possible to focus on the most relevant aspects, which will have a high impact on the company's profit.

To get things done, business units and IT might need completely new capabilities, structures and technologies, which might not be present within the company yet. In such a case, the best thing to do is to stop thinking through the existing structures, and think about (3) what really is required to execute the transformation process

1 This article intentionally avoids the discussion of end customers' needs analysis and focuses on internal analysis, assuming that the external analysis is provided by involved business units.

2 For an overview in Design Thinking see Uebernickel et al., 2015. 
and solve the identified use cases. The needs can be clustered into three areas: (1) people, (2) organization and (3) technologies and data. Following components can be identified within the specified areas:

1. People: (a) capabilities of business employees, (b) capabilities of IT employees, (c) digital maturity, (d) transitional mindset, (e) development potential, (f) capacities, (g) collaboration;

2. Organization: (a) strategy, (b) management support, (c) style of leadership, (d) culture, (e) structures, (f) processes, (g) communication, (h) common approaches, (i) regulations, (j) governance;

3. Technologies and data: (a) access to data, (b) access to technologies, (c) infrastructure.

Once what is vital to proceed with planned actions has been defined, the current status and the target state must be compared in order to identify the potentially remediable gaps. In case a gap is identified, companies are bound to find the way to compensate for it in order to achieve the goals. Depending on the size of organization, its flexibility, level of openness and digitalization it might be an easy task or a challenge to be addressed even in a few years. Once the gaps have been filled, the interdisciplinary IT-business teams can focus on solving certain business cases.

Finally, (4) focus should be on the execution of digital transformation program. The selected projects should be communicated in form of company's digital reform agenda, i.e. as a "G.E.T. stuff done" initiative (Rudder, 2016b). High level of transparency, achievable by continuous communication, is essential for a program's success. Therefore, the colleagues must be kept up-to-date on the project's status. It is essential for a transformation team to focus on achieving their project goals and continuously monitor the progress of their projects until they reach the successful project closure.

This article intentionally avoids the discussion of formal project approval, which might be necessary in most organizations. Since the processes and structures differ from organization to organization, transformation team should take their own particular cases into consideration to decide when to involve higher instances. It is to be remembered that management support in conducting transitions is vital to a successful realization and outcome. It does not, however, mean that the ideas for digital transformation must be created at the C-level. It just means that every employee needs an organizational and regulatory structure supporting her/him in the process, from idea to the implementation of her/his solution.

Depending on the projects transformation team has on the roadmap, profits may vary. These may include process optimization, risk reduction, cost reduction, increase in productivity, improved products or services, new revenue streams or even new business models.

Regular cooperation will lead to a raise of informal IT-business network within an enterprise, establishment of IT as a digital competence center and an increase in employees' digital maturity. Construction of a learning institution will have a considerably 
positive impact on employees' capabilities. Business and IT will start speaking a common language, which will make it easier to collaborate on future projects. By working hand in hand with business will strengthen the intrinsic motivation of IT members as they will start seeing business challenges as their own. In other words, they will not see problems as solely business or IT problems, but as our problems. Through supporting each other, the teams will start to trust each other. By gaining visibility and prestige, as well as by spreading success stories (Sweetwood, 2016, p. 132) IT's perception will automatically shift to the position of innovation-partner. Thanks to interdisciplinary teams and breaking down of know-how, organizational as well as technical silos, a shift is to be observed from IQ to $\mathrm{WeQ}^{3}$, which is synergy-driven intelligence of a team as a whole, where the sum of separated IQs is lower than the WeQ of a team consisting of the same people. This phenomenon can be also described as a network effect or ROC, return on collaboration (Frost \& Sullivan, 2016, pp. 6-7, 12). Solid IT-business relationship will lead to a lower percentage of uncontrolled shadow IT, resulting in a higher ROI of technology investments. Maintenance of available solutions and portfolio management will become easier and resources which have been duplicated in the past will be reduced.

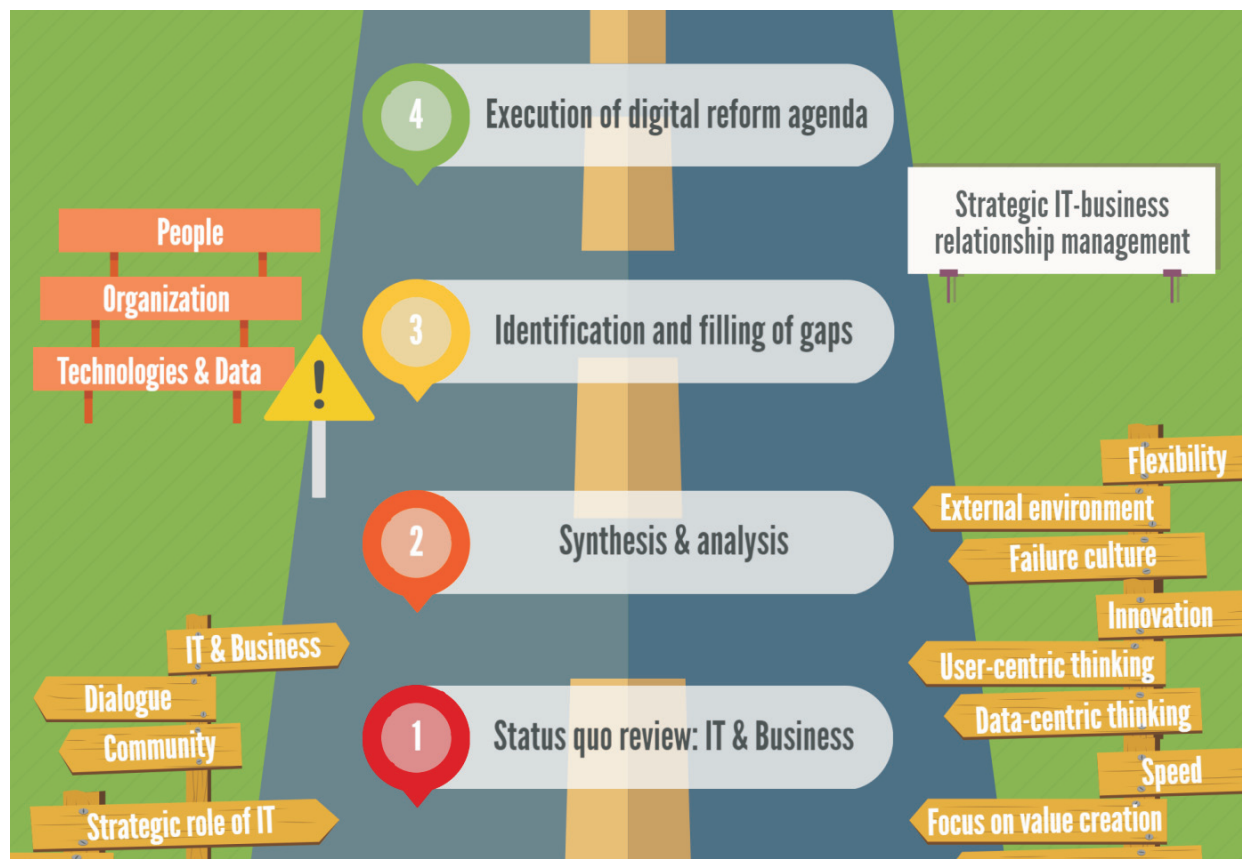

Fig. 3. Digital transformation roadmap

Source: own elaboration

3 For more information on WeQ see Weinberg, 2015 or Spiegel, 2015. 


\section{Stages of digital transformation: new perspective on Kurt Lewin's model}

Digital transformation is based on the principles of Kurt Lewin's change management process (Lewin, 1947, pp. 210-211). However, in the era of connected economy, the iteration of this process is the key success factor. To transform from laggards to disruptors, a company needs to go through four phases of digital transformation. (1) In the "unfreeze" phase, it is necessary to overcome institutional barriers, both in form of organization and mindset. This can be achieved by the community work described in the chapters above. Lewin's "change" phase can be split into two phases in case of digital transformation. (2) Once the company is ready and a new mindset has evolved, a digital workplace will be established by the digitization of the existing business processes. (3) At the next stage, company not only embraces open-transformational thinking, but also rethinks and redefines the existing processes and endeavors to create new innovation-led initiatives. (4) Successful disruption and transition from a non-digital native company into a company led by transformational thinking, as well as building sustainability of the change, can be described as the fourth and last phase of the first digital transformation cycle. Once a company succeeds in going through all four stages of transformation, it has to go back to phase one and start from the beginning, in order to disrupt itself once again.

\section{Conclusions}

The era of connected economy can be described as the twilight of digital native term, both for human beings and organizations. Digital native status is not sustainable. Due to the rapid technological advances, digital nativity is changing its definition with every groundbreaking digital innovation. The same principles apply to competitive advantage in the data-driven economy. Companies are facing a challenge of redefining themselves continually in order to stay competitive in a hypercompetitive and dynamic environment. Digital transformation is an iterative process of questioning the status-quo, a journey with no destination and no finish line. It is never finalized and always in the process of development: "Keep on innovating - it is never over. Every digital improvement (...) will open up new possibilities" (Westerman et al., 2014, p. 45).

Since nearly every activity is generating a digital footprint, these footprints have to be seen as potentially valuable assets, which have to be managed correctly. By a symbiosis of business and IT, organizations are most likely to gain a relatively deeper understanding of the digitally-driven world and necessary expertise for all digital processes. Therefore, companies must consider cross-departmental collaboration between IT and business units as a driver for digital transformation. 
As long as IT does not contribute to value creation process, it is a just a mere cost center. A CIO - possessing extremely valuable expertise highly necessary in the data-driven connected economy and understanding the threat of disruption - is obliged to transition the IT into a strategic partner, which is supporting business goals. Therefore, it is CIO's responsibility to make the C-suite aware of the real threats of digital disruption and initiate digital transformation. This responsibility stems from the moral obligation toward colleagues, who might lose their jobs in case the company misses the digitalization train. $\mathrm{CIO}$ as a digital transformation evangelist should make everyone aware of the new digital reality and inspire others to embrace the opportunities of the fourth industrial revolution.

Well designed and executed digital transformation roadmap will contribute to the establishment of solid IT-business relationship and IT's strategic role within the company, as well as - above all - to the digital-driven value creation process and in this way to company's competitive advantage. At this point, this work lastly makes a strong appeal to all CIOs: while your company is not yet on digital transformation track, not disrupting itself continuously, find the courage and do the first step in this direction, if your company and your colleagues matter to you!

\section{BIBLIOGRAPHY}

[1] Cox E., 2011, Retail Analytics: The Secret Weapon, John Wiley \& Sons, Hoboken, New Jersey.

[2] Lewin K., 1947, Group Decision and Social Change, [in:] Neweomb T.M, Hartley E.L., Readings in Social Psychology, Henry Holt and Co., New York.

[3] McQuivey J., 2013, Digital Disruption. Unleashing the Next Wave of Innovation, Forrester Research, Amazon Publishing, Las Vegas, Nevada.

[4] Peppard J., Ward J., 2016, The Strategic Management of Information Systems. Building a Digital Strategy, John Wiley \& Sons, Hoboken, New Jersey.

[5] Schumpeter J., 2003, Capitalism, Socialism and Democracy, Taylor \& Francis e-Library, Abingdon.

[6] SPIEgel P., 2015, WeQ - More than IQ: Abschied von der Ich-Kultur, oekom verlag, München.

[7] Sweetwood A., 2016, The Analytical Marketer. How to Transform Your Marketing Organization, Harvard Business Review Press, Boston, Massachusetts.

[8] Topinka J., 2014, IT Business Partnerships: A Field Guide, Paving the Way for Business \& Technology Convergence, CIO Mentor, Charlotte, South Carolina.

[9] Uebernickel F., Brenner W., Naef T., Pukall B., Schindlholzer B., 2015, Design Thinking. Das Handbuch, Frankfurter Allgemeine Buch, Frankfurt am Main.

[10] Weinberg U., 2015, Network Thinking, Murmann Publishers, Hamburg.

[11] Westerman G., Bonnet D., McAfee A., 2014, Leading Digital, Turning Technology into Business Transformation, Harvard Business Review Press, Boston, Massachusetts. 


\section{ELECTRONIC SOURCES}

[1] ADOBE, 2016, Adobe Kickbox, https://kickbox.adobe.com/ (10.12.2016).

[2] Boulton, C., 2016, CIOs Move More Dollars to Digital Transformation, http://www.cio.com/ article/3131927/cio-role/cios-move-more-dollars-to-digital-transformation.html (5.12.2016).

[3] CIO.com, 2015, 2015 State of the CIO, http://www.cio.com/article/2862760/cio-role/2015-state-of-the-cio.html\#slide5 (20.11.2016).

[4] CIO.com, 2016a, 2016 State of the CIO Survey. Exclusive Research from CIO, http://core0.staticworld.net/assets/2016/01/14/2016-state-of-the-cio-executive-summary.pdf (20.11.2016).

[5] CIO.com, 2016b, Just the Facts, State of the CIO 2016, http://core0.staticworld.net/assets/2016/02/08/ state_of_the_cio_just_the_facts.pdf (20.11.2016).

[6] DELOITTE, 2013, Digital Collaboration. Delivering innovation, productivity and happiness, https:// www2.deloitte.com/content/dam/Deloitte/se/Documents/technology-media-telecommunications/ deloitte-digital-collaboration.pdf (11.12.2016).

[7] Franklin R., 2016, Why cultivating curiosity in IT is more important than ever, https://enterprisersproject.com/article/2016/8/cultivating-curiosity-it (19.11.2016).

[8] FROST \& SULLIVAN, 2016, Meetings Around the World II: Charting the Course of Advanced Collaboration, http://www.verizonenterprise.com/resources/whitepapers/wp_meetings-aroundthe-world-ii_en_xg.pdf (11.12.2016).

[9] GARTNER, 2015, Gartner Says Bimodal IT Projects Require New Project Management Styles, http://www.gartner.com/newsroom/id/3036017 (11.12.2016).

[10] GARTNER, 2016a, Gartner Says Through 2018, 90 Percent of Organizations Will Lack a Postmodern Application Integration Strategy, http://www.gartner.com/newsroom/id/3233217 (11.12.2016).

[11] GARTNER, 2016b, Deliver on the Promise of Bimodal, https://www.gartner.com/doc/3216217/ deliver-promise-bimodal (11.12.2016).

[12] Gino F., 2016, Let Your Workers Rebel, Harvard Business Review, https://hbr.org/cover-story/2016/10/let-your-workers-rebel (10.12.2016).

[13] Hamari J., Sjöklint M., Ukкonen A., 2015, The Sharing Economy: Why People Participate in Collaborative Consumption, Journal of the Association for Information Science and Technology, https://people.uta.fi/ kljuham/2015-hamari_at_al-the_sharing_economy.pdf (9.12.2017).

[14] HARVARD BUSINESS REVIEW, 2016, The Ecosystem Equation: Collaboration in the Connected Economy, Harvard Business Review Analytic Services Report, https://hbr.org/resources/pdfs/ comm/ibm/19829_HBR_Report_IBM_June2016.pdf (5.12.2016).

[15] IDG ENTERPRISE, 2016, State of the CIO 2016, http://www.idgenterprise.com/resource/research/ tech-state-of-the-cio-2016/ (20.11.2016).

[16] Perry M.J., 2015, Fortune 500 firms in 1955 v. 2015; Only 12\% remain, thanks to the creative destruction that fuels economic prosperity, https://www.aei.org/publication/fortune-500-firms-in1955-vs-2015-only-12-remain-thanks-to-the-creative-destruction-that-fuels-economic-growth/ (4.12.2016).

[17] Rudder C., 2016a, After interviewing 40+ CIOs, executive recruiter Martha Heller shares insights for the "New Era of IT", https://enterprisersproject.com/article/2016/9/martha-heller-interviews40-cios-and-shares-tips-cios-new-era-it (5.12.2016).

[18] Rudder C., 2016b, FCC CIO encourages creative problem solving in IT through compassionate leadership, https://enterprisersproject.com/article/2016/10/fcc-cio-encourages-creative-problemsolving-it-through-compassionate-leadership (4.12.2016). 
[19] Segal M., 2016, 3 ways CIOs must adapt to thrive in a world of Digital Darwinism, https://enterprisersproject.com/article/2016/10/3-ways-cios-must-adapt-thrive-world-digital-darwinism (4.12.2016).

[20] Stackpole B., 2016, Meet tech's new odd couple, CIO.com, http://resources.idgenterprise.com/ original/AST-0161906_CIOD_FEB.pdf (20.11.2016).

[21] Verganti R., 2016, The Innovative Power of Criticism, Harvard Business Review, https://hbr. org/2016/01/the-innovative-power-of-criticism (11.12.2016).

[22] WORLD ECONOMIC FORUM, 2016, Agenda in Focus: The Fourth Industrial Revolution, https:// www.weforum.org/focus/fourth-industrial-revolution (18.12.2016). 